\title{
Utilization of sun-dried maize offal with blood meal in diets for broiler chickens
}

\author{
Olukayode A. Makinde*, Emmanuel B. Sonaiya \\ Department of Animal Sciences, Obafemi Awolowo University, Ile-Ife, Nigeria; \\ *Corresponding Author: olukayodemakinde@yahoo.com
}

Received 9 August 2011; revised 15 September 2011; accepted 28 September 2011.

\begin{abstract}
Sun-dried blend of maize offal and blood (SDMBM) was analyzed and its effect on the performance of broiler chickens (Anak-2000 strain) evaluated. Fresh blood prevented from coagulation, mixed with maize offal, was sun-dried, ground, mixed again with blood and ground into a meal after drying again. The crude protein, fat, fibre, ash, ADF and gross energy contents of SDMBM were, 362.0, 45.5, 31.8, 69.3, $52.3 \mathrm{~g} / \mathrm{kg}$ DM and $4.245 \mathrm{kcal} / \mathrm{g}$, respectively. It was adequate in all essential amino acids for growing broiler chickens except methionine. Eighty 14day-old commercial broiler chicks were randomly allocated to four dietary treatments (fed ad libitum; four replicates each) consisting the control diet (0 g SDMBM/kg diet), which contained fishmeal, groundnut cake and soybean meal, and three other diets $(50,100$ and $150 \mathrm{~g}$ SDMBM/kg diet). In a feeding trial, the starter (14 to $35 \mathrm{~d}$ ) and finisher (35 to $49 \mathrm{~d}$ ) dietary treatments did not have significant impact $(P>0.05)$ on body weight gain, efficiency of feed conversion, mortality and final body weights. The control diet was inferior $(P<0.05)$ to 50, 100 and 150 g SDMBM/kg diets for feed cost per unit weight gain in the starter phase, $100 \mathrm{~g}$ SDMBM/kg diet in the finisher phase, and 100 and $150 \mathrm{~g} \mathrm{SDMBM} /$ $\mathrm{kg}$ diets for the whole period (14 to $49 \mathrm{~d}$ ). Overall, the 100 and $150 \mathrm{~g}$ superior $(P<0.05)$ to the control diet in cost of production per unit weight gain and all the SDMBM diets greater than control in economic benefit per unit weight gain. Results suggest that dietary SDMBM up to $\mathbf{1 5 0}$ $\mathrm{g} / \mathrm{kg}$ diet has a positive effect on broiler performance and can totally replace more expensive fishmeal.
\end{abstract}

Keywords: Alternative Feedstuff; Blood Meal;
Fishmeal Replacement; Maize Offal

\section{INTRODUCTION}

In Nigeria, as in most other developing countries in the tropics, the transformation and use of agricultural by-products in livestock diets may have become more imperative due to increasing prices of grains (especially maize and oil seeds) globally and environmental pollution issues. However, many agricultural crop by-products in the tropics are fibrous (Abdelsamie et al. 1983; Longe and Fagbenro-Byron 1990) and this limits utilization in poultry production (Onifade 1993; Bolarinwa 1998). Nevertheless, the focus of current research is on fibre nutrition because of the issue of removal of antibiotics from feed and diversion of grains for ethanol and biodiesel production (Leeson 2008; Farrell 2008). The attraction is the suggested prebiotic attribute of fibrous feedstuffs (Sundu et al. 2006) and need to reduce feed costs by utilizing alternatives to maize as source of feed energy (Leeson 2008). An example of such alternatives is maize offal or maize bran.

Maize offal is a by-product of maize milling processes, second to wheat offal as the most preferred and utilized conventionally in livestock feeds in Nigeria (Babatunde et al. 2002). Maize offal contains about 110 to $120 \mathrm{~g} / \mathrm{kg}$ crude protein and 80 to $90 \mathrm{~g} / \mathrm{kg}$ crude fibre (Onifade and Babatunde 1998; Makinde 2006). The relatively low crude fibre content compared to other by-products could be an advantage in fibre nutrition whereas the low protein content appears to be a limitation.

Cattle blood is an abattoir by-product that directly affects the environment in Nigeria. Most of the blood from a considerable number of slaughter-cattle is wasted, not efficiently utilized, and pollutes the environment on a daily basis (Adeniji 1995; Makinde 2006). Paradoxically, blood meal, obtainable from cattle blood after drying, contains $80 \%$ - 90\% crude protein high in the essential amino acids, especially lysine (NRC 1994). Nevertheless, blood is very difficult to dry and is a good medium for 
microbial spoilage due to its high moisture content (Donkoh et al. 1999). Drying of blood requires high cost equipment coupled with facilities for central blood collection, which may be unaffordable and/or not applicable because the abattoir structure in Nigeria exists as smallscattered units. Moreover, previous work with blood involving sun drying in the development of alternative feedstuffs for poultry reported a long drying time of about three days (Adeniji 1995; Donkoh et al. 2002; Odunsi et al. 2004). However, previous studies by Sonaiya (1988) suggested the use of crop by-product materials as absorbents for blood in order to increase the surface area for quicker sun drying.

Makinde and Sonaiya (2007, 2010) have reported a simple processing procedure, nutrient composition and optimum mixing ratios for crop by-products with blood including maize offal. The procedure resulted in quicker sun drying of blood $(<4 \mathrm{~h})$, enhancement of the crude protein content of maize offal by the blood mixed and a way to contribute towards reduction of environmental pollution from abattoirs.

However, nutritional information on the utilization of such a sun-dried maize offal blood meal (SDMBM) by broiler chickens was unavailable. Consequently, the objective was to provide data on the utilisation of SDMBM by broiler chickens when fed diets with increasing quantities of SDMBM.

\section{MATERIALS AND METHODS}

\subsection{Preparation of SDBM and Nutrient Composition}

Sun-dried maize offal blood meal was prepared and analysed for nutrient composition according to the procedures previously described by Makinde and Sonaiya (2007, 2010). Briefly, maize offal (source, Eagle Flour Mills, Ibadan, Nigeria) was hand-mixed (1:1 w/w) with fresh blood (prevented from coagulating for at least 6 hours by mixing with $18 \mathrm{~g}$ common salt/litre blood) collected from several slaughtered cattle at a commercial abattoir. This mixture was sun-dried for between 3 to $4 \mathrm{~h}$, ground, mixed again with blood (5:4 w/w) and ground into a meal after drying again.

Nutrient composition (proximate composition and acid detergent fibre (ADF) inclusive of residual ash) of maize offal and SDMBM were determined using standard procedures of AOAC (1990). Gross energy was determined by oxygen bomb calorimeter (Gallenkamp Ballistic Bomb Calorimeter, Cambridge Instrument Co. Ltd, England). Meal samples were prepared and analysed for mineral concentrations following the methods described by Fick et al. (1979). Amino acid composition of SDMBM was determined following acid hydrolysis using a Techni- con $^{\circledR}$ Sequential Multisample Amino Acid Analyzer (TSM-1, model DNA 0209, Swords Co., Dublin, Ireland; reproducibility, $\pm 3 \%$ ) at the Zoology Department, University of Jos, Jos, Nigeria. Between 30-50mg of the defatted sample was weighed into glass ampoule. Seven millilitres of $6 \mathrm{~N} \mathrm{HCl}$ was added and oxygen was expelled by passing nitrogen into the ampoule (this was to avoid or reduce possible oxidation of sulphur amino acids during hydrolysis). The glass ampoule was then sealed with bunsen burner flame and put in an oven preset at $105^{\circ} \mathrm{C} \pm 5^{\circ} \mathrm{C}$ for 22 hours.

\subsection{Experimental Procedure and Management of Birds}

The experiment was in two phases, starter and finisher phases. Eighty 14-day-old commercial broiler chicks (Anak-2000 strain) were randomly allocated to one of four dietary treatments (Table 1) in a completely randomized block design. Each treatment was replicated four times with five birds per replicate. The dietary treatments consisted of the control diet, which contained fishmeal (starter diet only), groundnut cake and soybean meal as the main protein sources, and three other diets, which contained varying levels of SDMBM at 50, 100, and $150 \mathrm{~g} / \mathrm{kg}$ diet. Two control diets were formulated, one for the starter phase containing no SDMBM but fishmeal at $30 \mathrm{~g} / \mathrm{kg}$ diet, and the other for the finisher phase with no fishmeal or any other animal protein source. The test diets for the starter phase were formulated to be isocaloric and isonitrogenous containing $3000 \mathrm{kcal}$ $\mathrm{ME} / \mathrm{kg}$ and 22\% crude protein (PTF 1992), and the finisher phase formulated to contain $2950 \mathrm{kcal} \mathrm{ME} / \mathrm{kg}$ and 18\% crude protein (PTF 1992). The starter diet was fed for 3 weeks, and the finisher diet for 2 weeks. The birds were confined in 20 floor pens (each measuring $1.52 \mathrm{~m}^{2}$ ) which provided a floor space of $0.3 \mathrm{~m}^{2}$ per bird. The pens were in a poultry house constructed from wood and wire gauze, with asbestos roof and concrete floor. Pens were covered with wood shavings for bedding. Plastic water drinkers and suspended metallic conical feeders were used to provide drink and feed, respectively, and were cleaned daily.

Birds were fed ad libitum with free access to water. Newcastle disease vaccine (NDV), infectious bursal disease vaccine (IBDV), coccidiostat (Embazin-Forte ${ }^{\circledR}$ : Sulfaquinoxaline-Diaveridine-Vitamin $\mathrm{K}$ complex), antibiotic (Keproceryl ${ }^{\circledR}$ : water-soluble mix of the antibioticsoxytetracycline, erythromycin, and streptomycin with fatand water-soluble vitamins), and a B-vitamin complex solution (Biovit ${ }^{\circledR}$ ) as antistress were used to maintain chicks in good health. The coccidiostat, antibiotic, and B-vitamins drug were administered via the drinking water.

All five chickens in each pen were weighed individu- 
Table 1. Gross and nutrient composition of experimental broiler starter and finisher diets.

\begin{tabular}{|c|c|c|c|c|c|c|c|c|}
\hline \multirow[b]{3}{*}{ Ingredients } & \multicolumn{8}{|c|}{$\mathrm{SDMBM}^{1}$ (g/kg diet) } \\
\hline & \multicolumn{4}{|c|}{ Starter } & \multicolumn{4}{|c|}{ Finisher } \\
\hline & 0 & 50 & 100 & 150 & 0 & 50 & 100 & 150 \\
\hline Maize & 589.4 & 580.5 & 600 & 541.5 & 614.2 & 610.5 & 610 & 607.9 \\
\hline Soya bean meal & 160 & 127 & 28 & 32 & 158 & 120 & 100 & 96 \\
\hline Groundnut cake & 145 & 203 & 237 & 228 & 70 & 85 & 73.5 & 48 \\
\hline Fishmeal & 30 & 0 & 0 & 0 & 0 & 0 & 0 & 0 \\
\hline SDMBM & 0 & 50 & 100 & 150 & 0 & 50 & 100 & 150 \\
\hline Wheat offal & 40.6 & 4.5 & 0 & 0 & 122.8 & 99.5 & 81.5 & 63.1 \\
\hline Bone meal & 27 & 27 & 27 & 27 & 27 & 27 & 27 & 27 \\
\hline Premix $^{3}$ & 2.5 & 2.5 & 2.5 & 2.5 & 2.5 & 2.5 & 2.5 & 2.5 \\
\hline Salt & 2.5 & 2.5 & 2.5 & 2.5 & 2.5 & 2.5 & 2.5 & 2.5 \\
\hline Lysine & 1.5 & 1.5 & 1.5 & 1.5 & 1.5 & 1.5 & 1.5 & 1.5 \\
\hline Methionine & 1.5 & 1.5 & 1.5 & 1.5 & 1.5 & 1.5 & 1.5 & 1.5 \\
\hline \multicolumn{9}{|c|}{ Calculated composition ${ }^{3}$} \\
\hline $\mathrm{ME}$ in $\mathrm{kcal} / \mathrm{kg}$ & 3000.52 & 3000.22 & 3000.78 & 3000.98 & 2950.2 & 2950.47 & 2950.29 & 2950.1 \\
\hline$\%$ СР & 22.19 & 22.03 & 22.2 & 22.06 & 18.02 & 18.35 & 18.35 & 18.38 \\
\hline$\% \mathrm{CF}$ & 3.32 & 3.48 & 3.45 & 3.76 & 3.65 & 3.71 & 3.82 & 3.95 \\
\hline$\% \mathrm{Ca}$ & 1.26 & 1.08 & 1.07 & 1.07 & 1.07 & 1.06 & 1.06 & 1.06 \\
\hline$\% \mathrm{P}$ & 0.96 & 0.75 & 0.67 & 0.68 & 0.79 & 0.75 & 0.73 & 0.72 \\
\hline \%Lysine & 1.15 & 1.09 & 1 & 1.09 & 0.97 & 1.03 & 0.98 & 1.02 \\
\hline \%Methionine & 0.48 & 0.45 & 0.45 & 0.46 & 0.42 & 0.42 & 0.42 & 0.42 \\
\hline Cost of diet (N/kg) & 60.79 & 55.73 & 51.58 & 50.21 & 54.06 & 53.4 & 53.33 & 53.72 \\
\hline
\end{tabular}

${ }^{1}$ SDMBM = sun-dried maize offal blood meal. ²Provides per kg of diet: Vitamin A, 12,500 IU; Vitamin D, 2,500 IU; Vitamin E, 40 mg; Vitamin K, 2 mg; Vitamin B1, 3 mg; Vitamin B2, 5.5 mg; Niacin 55 mg; Calcium pantothenate, 11.5 mg; Vitamin B 6, 5mg; Vitamin B $12,0.025$ mg; Choline chloride, 500 mg; Folic acid, 1 mg; Biotin, 0.08 mg; Manganese, 120 mg; Iron, 100 mg; Zinc, 80 mg; Copper, 8.5 mg; Iodine, 1.5 mg; Cobalt, 0.3 mg; Selenium, 0.12 mg; Anti-oxidant, $120 \mathrm{mg} .{ }^{3} \mathrm{ME}=$ metabolizable energy; $\mathrm{CP}=$ crude protein; $\mathrm{CF}=$ crude fibre; $\mathrm{Ca}=$ calcium; $\mathrm{P}=$ phosphorous (total).

ally at the beginning of the experiment, then weekly, and at the end of the experiment. Feed consumption per pen was recorded weekly after the total feed given per week was corrected for feed left over. Average daily gain (ADG), average daily feed intake (ADFI), feed conversion ratio (FCR), were calculated from the data obtained. Records of mortality were kept and all dead chickens examined post-mortem by veterinarians. At the end of the experiment, three birds were selected randomly from each pen, starved of feed for 24 hours to empty their crops, killed by cutting the jugular vein, exsaguinated, defeathered and eviscerated. Carcass yield calculated as dressed weight per unit live weight excluded all the organs, head, feathers, neck and shanks. Economics of production were evaluated in terms of feed cost $/ \mathrm{kg}$ feed, feed cost $/ \mathrm{kg}$ gain, cost of production $/ \mathrm{kg}$ gain, and bene$\mathrm{fit} / \mathrm{kg}$ gain.

\subsection{Statistical Analysis}

Data were analyzed as completely randomized block design using the General Linear Means procedure of SAS (2000) for analysis of variance (ANOVA). The effects of the four dietary treatments $(0,50,100$, and $150 \mathrm{~g}$ $\mathrm{SDMBM} / \mathrm{kg}$ diet) were tested on broiler performance at both starter and finisher phases, and overall. The four replicates per treatment were considered as blocks in order to increase the sensitivity of the experiment by reducing the residual error. Differences between means 
were resolved by Duncan's multiple range test of the SAS statistical package. Statistical significance was established when probability was less than 0.05 level of significance.

\section{RESULTS AND DISCUSSION}

It was observed that when maize offal was handmixed with blood it soon became viscous or thick and then rubbery. Therefore, the mixture needed to be mixed quickly and sun-dried very soon after. This attribute will be important in the scaling up of the procedure regarding the design of a mechanical mixer for small-, medium- or large-scale application. In addition, there will be need for suitable ovens that could be applied in the wet season when sunshine hours are critically reduced.

The chemical composition of maize offal, SDMBM, and vat-dried blood meal are shown in Table 2. In comparison with maize offal and vat-dried blood meal, SDMBM was drier as indicated by the moisture content (76 vs. 96.7 and $80 \mathrm{~g}$ moisture/kg, respectively). According to Rozis (1997), a moisture content of between 100 to $120 \mathrm{~g}$ moisture/kg is satisfactory for most agricultural products. The gross energy contents of SDMBM and maize offal were comparable; whereas crude protein was three times higher and crude fibre three times lower for SDMBM. This indicates that mixing blood to maize offal improved its nutrient quality and potential usefulness in livestock feeding especially monogastrics. Further, the amino acid composition of SDMBM compared with NRC (1994) amino acid requirements for broiler chickens (0 to 8 weeks of age) shows that it is adequate in all essential amino acids except methionine (4.0 vs. $5.0 \mathrm{~g} / \mathrm{kg}$ ). Moreover, SDMBM had very marginal content of mineral elements when compared with vat-dried blood meal. However, the use of synthetic methionine sources, mineral element supplements and premixes, conventionally used in diets, should overcome these deficiencies

Data showing the effect of dietary SDMBM on the growth performance of the broiler chickens at the starter phase (days 14 to 35), finisher phase (days 35 to 49), and overall (days 14 to 49 ) is shown in Table 3 . In both the starter and finisher phases, average final body weights (AFBW), average daily body weight gain (ADG), and feed conversion ratio (FCR) varied between diets but were not significantly different $(\mathrm{P}>0.05)$, as well as for average final body weight (AFBW), feed conversion ratio (FCR) and carcass yield in the whole period (days 14 to 49). These results suggest that the SDMBM diets were not inferior to the control diet with fishmeal. This appears to attest to the quality of SDMBM as possessing additive attributes of blood as a high quality protein. A significant $(\mathrm{P}<0.05)$ depression in average daily feed intake (ADFI) was obtained for the $100 \mathrm{~g}$ SDMBM/kg diet compared with the control in the starter phase (Table 3). This was probably due to the inexplicable poor growth of one of the birds in one replicate pen observed the penultimate week of the starter period, which after culling eventually died same week. However, postmortem autopsies indicated no specific causes for deaths

Table 2. Chemical composition of maize offal, sun-dried maize offal blood meal, and vat-dried blood meal ${ }^{1}$.

\begin{tabular}{|c|c|c|c|}
\hline & Maize & $\mathrm{SDMBM}^{2}$ & Vat dried ${ }^{3}$ \\
\hline Composition (g/kg DM) & offal & & blood meal \\
\hline Dry Matter & 903.3 & 924.0 & 920 \\
\hline Gross energy, kcal/g & 4.273 & 4.245 & 5.21 \\
\hline Crude protein & 111.6 & 334.0 & 771.0 \\
\hline Arginine & NA & 14.3 & 33.4 \\
\hline Histidine & NA & 10.4 & 50.6 \\
\hline Isoleucine & NA & 10.7 & 9.1 \\
\hline Leucine & NA & 30.7 & 109.9 \\
\hline Lysine & NA & 11.0 & 70.4 \\
\hline Methionine & NA & 4.0 & 9.9 \\
\hline Phenylalanine & NA & 14.2 & 53.4 \\
\hline Threonine & NA & 8.3 & 40.5 \\
\hline Valine & NA & 11.7 & 70.5 \\
\hline Alanine & NA & 10.1 & NA \\
\hline Aspartic acid & NA & 23.3 & NA \\
\hline Cystine & NA & 5.7 & NA \\
\hline Glutamic acid & NA & 26.0 & NA \\
\hline Glycine & NA & 11.0 & 45.9 \\
\hline Proline & NA & 8.8 & NA \\
\hline Serine & NA & 6.8 & 31.4 \\
\hline Tyrosine & NA & 1.0 & 20.7 \\
\hline Tryptophan & NA & NA & NA \\
\hline Crude fibre & 87.6 & 31.8 & 5.5 \\
\hline $\mathrm{ADF}^{4}$ & 285.0 & 52.3 & 18.0 \\
\hline Ether extract & 65.0 & 45.5 & 16.0 \\
\hline NFE & 596.0 & 511.8 & NA \\
\hline Ash & 42.7 & 69.3 & NA \\
\hline $\mathrm{Ca}, \mathrm{mg} / \mathrm{kg}$ & NA & 0.08 & 3700.0 \\
\hline $\mathrm{P}, \mathrm{mg} / \mathrm{kg}$ & NA & 4.4 & 2700.0 \\
\hline $\mathrm{Mg}, \mathrm{mg} / \mathrm{kg}$ & NA & 37.0 & 1100.0 \\
\hline $\mathrm{Fe}, \mathrm{mg} / \mathrm{kg}$ & NA & 6.8 & $1,922.0$ \\
\hline $\mathrm{Mn}, \mathrm{mg} / \mathrm{kg}$ & NA & 0.79 & 6.0 \\
\hline $\mathrm{Cu}, \mathrm{mg} / \mathrm{kg}$ & NA & 3.19 & 11.0 \\
\hline $\mathrm{Zn}, \mathrm{mg} / \mathrm{kg}$ & NA & 0.01 & 38.0 \\
\hline
\end{tabular}

${ }^{1}$ Values are means of duplicate samples; NA $=$ Not analysed. ${ }^{2}$ SDMBM $=$ sun-dried maize offal blood meal (Makinde and Sonaiya 2010). ${ }^{3}$ Values obtained from from NRC (1994) and NRC (1998). ${ }^{4} \mathrm{ADF}=$ neutral detergent fibre. 
Table 3. Live performance (14 to 35, 35 to 49 , and 14 to 49 d) of broiler chickens fed diets with graded levels of sun-dried maize offal blood meal.

\begin{tabular}{|c|c|c|c|c|c|c|c|c|c|c|c|c|c|c|c|}
\hline \multirow[b]{3}{*}{ Parameters } & \multicolumn{4}{|c|}{ Starter (14 to35 d) } & \multicolumn{5}{|c|}{ Finisher (35 to 49 d) } & \multirow[b]{3}{*}{ SE } & \multicolumn{4}{|c|}{ Overall (14 to 49 d) } & \multirow[b]{3}{*}{ SE } \\
\hline & \multicolumn{4}{|c|}{ Levels of $\mathrm{SDMBM}^{1}$ (g/kg diet) } & \multirow[b]{2}{*}{$\mathrm{SE}^{2}$} & \multicolumn{4}{|c|}{ Levels of SDMBM (g/kg diet) } & & \multicolumn{4}{|c|}{ Levels of SDMBM (g/kg diet) } & \\
\hline & 0 & 50 & 100 & 150 & & 0 & 50 & 100 & 150 & & 0 & 50 & 100 & 150 & \\
\hline $\operatorname{AIB}(\mathrm{g} / \mathrm{bird})^{3}$ & 227.25 & 212.35 & 221 & 210.55 & - & 948.18 & 936.54 & 858.6 & 941.7 & - & 227.25 & 212.35 & 221 & 210.55 & - \\
\hline AFBW (g/bird) ${ }^{4}$ & 948.18 & 936.54 & 858.6 & 941.7 & 9.10 & 1639.16 & 1715.24 & 1549.7 & 1667.3 & 17.50 & 1639.16 & 1715.24 & 1549.7 & 1667.3 & 17.50 \\
\hline ADG (g/bird) $)^{5}$ & 34.33 & 34.49 & 30.36 & 34.82 & 0.30 & 49.36 & 55.62 & 49.36 & 51.83 & 1.30 & $40.34^{\mathrm{ab}}$ & $42.94^{\mathrm{a}}$ & $37.96^{\mathrm{b}}$ & $41.62^{\mathrm{ab}}$ & 0.55 \\
\hline ADFI (g/bird) ${ }^{6}$ & $81.20^{\mathrm{a}}$ & $76.98^{\mathrm{ab}}$ & $72.47^{\mathrm{b}}$ & $76.55^{\mathrm{ab}}$ & 0.58 & $163.80^{\mathrm{a}}$ & $163.45^{\mathrm{a}}$ & $139.86^{\mathrm{b}}$ & $154.11^{\mathrm{a}}$ & 1.44 & $110.82^{\mathrm{a}}$ & $111.57^{\mathrm{a}}$ & $99.43^{\mathrm{b}}$ & $107.56^{\mathrm{a}}$ & 0.86 \\
\hline $\mathrm{FCR}^{7}$ & 2.37 & 2.25 & 2.4 & 2.21 & 0.02 & 3.32 & 2.95 & 2.88 & 2.98 & 0.08 & 2.75 & 2.61 & 2.64 & 2.59 & 0.03 \\
\hline Carcass yield (\%) & - & - & - & - & - & - & - & - & - & - & 62.01 & 65.54 & 64.16 & 63.71 & 0.41 \\
\hline Mortality (number) & 1 & 0 & 1 & 0 & - & 0 & 0 & 0 & 0 & - & 1 & 0 & 1 & 0 & - \\
\hline $\mathrm{FC} / \mathrm{kg}(\mathrm{N})^{8}$ & 60.79 & 55.73 & 51.58 & 50.21 & - & 54.06 & 53.4 & 53.33 & 53.72 & - & 57.43 & 54.57 & 52.46 & 51.97 & - \\
\hline FC/kg gain $(\mathrm{N})$ & $143.88^{\mathrm{a}}$ & $125.6^{\mathrm{b}}$ & $123.89^{\mathrm{b}}$ & $111.08^{\mathrm{b}}$ & 1.90 & $179.75^{\mathrm{a}}$ & $157.69^{\mathrm{ab}}$ & $157.18^{\mathrm{b}}$ & $160^{\mathrm{ab}}$ & 2.70 & $157.83^{\mathrm{a}}$ & $142.49^{\mathrm{ab}}$ & $138.40^{\mathrm{b}}$ & $134.42^{\mathrm{b}}$ & 1.7 \\
\hline $\mathrm{CP} / \mathrm{kg} \operatorname{gain}^{9}(\mathrm{~N})$ & - & - & - & - & - & - & - & - & - & - & $341.83^{\mathrm{a}}$ & $326.49^{\mathrm{ab}}$ & $322.40^{\mathrm{b}}$ & $318.42^{\mathrm{b}}$ & 1.7 \\
\hline 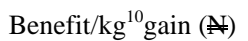 & - & - & - & - & - & - & - & - & - & - & $58.17^{\mathrm{b}}$ & $73.03^{\mathrm{a}}$ & $77.60^{\mathrm{a}}$ & $81.56^{\mathrm{a}}$ & 1.7 \\
\hline
\end{tabular}

${ }^{\mathrm{ab}}$ Means on the same row with the same superscripts are not significantly different $(\mathrm{P}>0.05) .{ }^{1} \mathrm{SDMBM}=$ sun-dried maize offal blood meal. ${ }^{2} \mathrm{SE}=$ standard error of means. ${ }^{3} \mathrm{AIB}=$ average initial body weight. ${ }^{4} \mathrm{AFBW}=$ average final body weight. ${ }^{5} \mathrm{ADG}=$ average daily gain. ${ }^{6} \mathrm{ADFI}=$ average daily feed intake. ${ }^{7} \mathrm{FCR}$ $=$ feed conversion ratio ( $\mathrm{g}$ feed/g gain). ${ }^{8} \mathrm{FC}=$ feed cost $\left(\mathrm{N}=\right.$ Naira). ${ }^{9} \mathrm{CP}=$ cost of production $/ \mathrm{kg}$ gain $(\mathrm{N})=\mathrm{FC} / \mathrm{kg}$ gain + Total common costs for 49 days (brooded chicks; drugs; equipment; wood shavings; transportation; poultry house repair and maintainnance; labour and miscellaneous-10\% of total common costs). ${ }^{10}$ Benefit $/ \mathrm{kg}$ gain $(\mathrm{N})=$ price of broiler $/ \mathrm{kg}(\mathrm{N})$ when study was conducted $(\mathrm{N} 400.00)$ minus cost of production $/ \mathrm{kg}$ gain $(\mathrm{N}) ; 1 \mathrm{US} \$=\mathrm{N} 150$.

that can be attributable to the diet. The depression in feed consumption for the $100 \mathrm{~g}$ SDMBM/kg dietary treatment in the finisher phase is obscured to this study. It is possible that the birds in the pen where mortality occurred had unidentified sub-clinical level infection, which depressed feed intake. The same reason could be advanced for the feed consumption that was significantly ( $\mathrm{P}<0.05$ ) depressed and the least ADG overall for the $100 \mathrm{~g} \mathrm{SDMBM} / \mathrm{kg}$ diet compared with other diets.

Economically, the SDMBM diets were generally superior to the control for all growth periods in terms of feed cost per $\mathrm{kg}$ (FC/kg), feed cost per $\mathrm{kg}$ live weight gain (FC/kg gain), cost of production per $\mathrm{kg}$ live weight gain (CP/kg gain), and profit or benefit per bird. The 150 g SDMBM/kg dietary treatment had the highest profit compared with the control, which was least $(\mathrm{P}<0.05)$. Khawaja et al. (2007) and Donkoh et al. (2003) obtained similar results on superior economic benefits for blood meal and a blend of blood and ground maize cob in broilers, respectively.

\section{CONCLUSIONS}

The findings under the conditions of this study show that there are no adverse effects on growth performance by incorporating SDMBM, a simple suitable alternative protein source to fishmeal, up to $150 \mathrm{~g}$ SDMBM/kg in the starter and finisher diets of broiler chickens. Further investigations are needed concerning a scaling up of the production process and possible effects of mechanical drying on nutritional quality of SDMBM.

\section{ACKNOWLEDGEMENTS}

Raw Materials Research and Development Council (RMRDC), Abuja, Nigeria provided funding for the research reported in this article. $\mathrm{Mr}$ J. O. S. Adeyeye and the workers at the Araromi Abattoir, Ile-Ife, Osun State, Nigeria are also appreciated for their cooperation and assistance.

\section{REFERENCES}

[1] Abdelsamie, R. E, Ranaweera, K. N. P. and Nano, W. E. (1983) The influence of fibre content and physical texture of the diet on the performance of broilers in the tropics. British Poultry Science, 24, 383-390. doi:10.1080/00071668308416752

[2] Adeniji, A. A. (1995) The value of bovine blood-rumen content meal as a feedstuff for pullets. Ph.D Thesis, University of Ilorin, Ilorin, Nigeria.

[3] AOAC (1990) Asssociation of Official Analytical Chemists. Official Methods of Analysis, 15th Edition, AOAC, Arlington Virginia, USA.

[4] Babatunde, B. B., Oluyemi, J. A., Adejinmi, O. O. and Olupona, J. A. (2002) Preference of commercial feed millers and poultry farmers for fibrous ingredients and 
their dietary levels. In: Aletor, V. A. and Onibi, G. E., Eds., Increasing household protein consumption through improved livestock production. Proceedings of the 27th Annual Conference of the Nigerian Society for Animal Production, Federal University of Technology, Akure, Ondo State, Nigeria, 264-266.

[5] Bolarinwa, B. B. (1998) Evaluation and optimum use of fibrous ingredients in the diets of broilers. Ph.D. Thesis, University of Ibadan, Ibadan, Nigeria. Giambastiani, B.M.S. (2007) Evoluzione idrologica ed idrogeologica della pineta di San Vitale (Ravenna). Ph.D. Thesis, Bologna University, Bologna.

[6] Donkoh, A., Atuahene, C.C., Anang, D. M. and Ofori, S. K. (1999) Chemical composition of solar-dried blood meal and its effect on performance of broiler chickens. Animal Feed Science and Technology, 81, 299-307. doi:10.1016/S0377-8401(99)00069-3

[7] Donkoh, A., Atuahene, C.C., Anang, D. M. and Hagan, M. A. S. (2002) Influence of processing temperature on chemical composition of solar-dried blood meal and on performance of broiler chickens. Journal of Animal and Feed Sciences, 11, 299-307.

[8] Donkoh, A., Otchere, S., Asare, U. O., Okyere-Boakye, E., Tawiah, R. Y. and Nyannor, E. K. D. (2003) A note on nutritive value of blend of blood and ground maize cob for broiler chickens. Journal of Animal and Feed Sciences, 12, 597-603.

[9] Farrell, D. (2008) Future eaters. World's Poultry Science Journal, 64, 102.

[10] Fick, K. R., McDowell, L. R., Miles, P. H., Wilkinson, N. S., Funk, J. D. and Conrad, J. H. (1979) Methods of Mineral Analysis for Plant and Animal Tissues, 2nd Edition, Department of Animal Science, University of Florida, Gainesville, FL, USA.

[11] Khawaja, T., Khan, S. H. and Ansari, N. A. (2007) Effect of different levels of blood meal on broiler performance during two phases of growth. International Journal of Poultry Science, 6, 860-865. doi:10.3923/ijps.2007.860.865

[12] Leeson, S. (2008) Poultry nutrition, future prospects. World's Poultry Science Journal, 64, 99.

[13] Longe, O. G. and Fagbenro-Byron, J. O. (1990) Composition and physical characteristics of some fibrous wastes and by-products for pig feeds in Nigeria. Journal of Tropical Agriculture and Veterinary Science, 28, 199-205.

[14] Makinde, O. A. (2006) Processing of vegetable-carried bovine blood meal and its utilization by poultry and fish. Ph.D. Thesis, Obafemi Awolowo University, Ile-Ife, Nigeria.
[15] Makinde, O. A. and Sonaiya, E. B. (2007) Determination of water, blood and rumen fluid absorbencies of some fibrous feedstuffs. Livestock Research for Rural Development, 19. http://www.lrrd.org/lrrd19/10/maki19156.htm

[16] Makinde, O. A. and Sonaiya, E. B. (2010) A simple technology for production of vegetable-carried blood or rumen fluid meals from abattoir wastes. Animal Feed Science and Technology, 162, 12-19. doi:10.1016/j.anifeedsci.2010.08.011

[17] NRC (1994) National Research Council. Nutrient requirements of domestic animals. Nutrient requirements of poultry, 9th revised Edition, National Academy Press. Washington, DC., USA.

[18] NRC (1998) National Research Council. Nutrient requirements of domestic animals. Nutrient requirements of swine, 10th revised Edition, National Academy Press, Washington, DC., USA.

[19] Odunsi, A. A., Akingbade, A. A. and Farinu, G. O. (2004) Effect of bovine blood-rumen digesta mixture on growth performance, nutrient retention and carcass characteristics of broiler chickens. Journal of Animal and Veterinary Advances, 3, 663-667.

[20] Onifade, A. A. (1993) Comparative utilization of three dietary fibres in broiler chickens. Ph.D. Thesis, University of Ibadan, Ibadan, Nigeria.

[21] Onifade, A. A. and Babatunde, G. M. (1998) Comparison of the utilization of palm kernel meal, brewers dried grains and maize offal by broiler chicks. British Poultry Science, 39, 245-250. doi:10.1080/00071669889204

[22] PTF (1992) Presidential Task Force on Alternative Formulations of Livestock Feeds. Report on livestock numbers, feed resources, inventory and supplies, Office of the Secretary to the government of the Federal Republic of Nigeria, Abuja, FCT, 2.

[23] Rozis, Jean-Francois. (1997) Drying foodstuffs-techniques, processes, equipment technical guidebook. GeresFrench Ministry of Co-operation-Neda-CTA. Bachuys Publishers Leiden, The Netherlands.

[24] SAS (2000) Statistical Analysis Systems. Guide for personal computers. Release 8.1. SAS institute Inc., Cary, NC, USA.

[25] Sonaiya, E. B. (1988) Animal by-products and their potential for commercial livestock feed production. In: Babatunde G. M., Eds., Proceedings of a National Workshop on Alternative Feeds in Nigeria, ARMTI, Ilorin, Kwara State, Nigeria, 298-315.

[26] Sundu, B., Kumar, A. and Dingle, J. (2006) Palm kernel meal in broiler diets: Effect on chicken performance and health. World's Poultry Science Journal, 62, 316-337. $\underline{\text { doi:10.1079/WPS2005100 }}$ 